\title{
MEMBANGUN KARAKTER SISWA MELALUI PENDIDIKAN “UNGGAH UNGGUH” DI SEKOLAH
}

\author{
Oleh: \\ Triwahyu Budiutomo \\ Universitas Cokroaminoto Yogyakarta
}

\begin{abstract}
Abstrak
Kemerotan moral mendera bangsa kita saat ini, antara lain tingginya tingkat kriminalitas, kasus korupsi, kolusi dan penegakan hukum yang sepertinya masih jauh dari harapan nilai keadilan. Kejadian tersebut memberi kesan seakan-akan bangsa kita sedang mengalami krisis etika dan krisis kepercayaan diri yang berkepanjangan. Berdasarkan kenyataan tersebut, pendidikan nilai/moral memang sangat diperlukan atas dasar argumen adanya kebutuhan nyata dan mendesak. Dalam Permendiknas N0.45/2006 setiap rumusan SKL secara implisit dan eksplisit termuat substansi nilai/karakter. Pendidikan unggah-ungguh di sekolah diberikan merupakan pelaksanaan mata pelajaran Seni Budaya. Pendidikan unggah-ungguh diberikan karena keunikan, kebermaknaan dan kebermanfaatan terhadap kebutuhan perkembangan siswa, yang terletak pada pemberian pengalaman etik dan estetik dalam bentuk kegiatan berekspresi/berkreasi dan berapresiasi. Prinsip dan Pendekatan Pendidikan Karakter terintegrasi kedalam mata pelajaran, pengembangan diri dan budaya sekolah. Oleh karena itu, guru dan sekolah perlu mengintegrasikan nilai-nilai yang dikembangkan dalam pendidikan budaya dan karakter bangsa ke dalam Kurikulum Tingkat Satuan Pendidikan (KTSP, silabus dan RPP). Prinsip ini membawa peserta didik belajar melalui proses berpikir, bersikap, dan berbuat. Dengan demikian membangun karakter siswa dengan pembelajaran unggah ungguh dapat dilaksanakan melalui kegiatan sekolah dan proses pembelajaran di kelas, sehingga pembelajaran unggah ungguh di sekolah dapat sebagai sarana membangun karakter siswa untuk membentuk insan yang berkualitas.
\end{abstract}

Kata kunci: karakter, pembelajaran unggah ungguh

\section{Pendahuluan}

Berangkat dari rasa keprihatinan atas kondisi bangsa kita dengan maraknya peristiwaperistiwa yang mendera saat ini, antara lain tingginya tingkat kriminalitas, tingginya kasus korupsi, dan penegakan hukum yang sepertinya masih jauh dari harapan nilai keadilan. Ditambah pula berkembangnya acara-acara tayangan di media cetak maupun noncetak (jaringan maya, televisi, dll) yang memuat fenomena dan kasus perseteruan dalam berbagai kalangan misal: tawuran antar remaja, antar sekolah, antar warga, pornografi dan pornoaksi, dan lain-lain. 
Kejadian tersebut memberi kesan seakan-akan bangsa kita sedang mengalami krisis etika dan krisis kepercayaan diri yang berkepanjangan. Berdasarkan kenyataan tersebut, pendidikan nilai/moral memang sangat diperlukan atas dasar argumen adanya kebutuhan nyata dan mendesak, dan dapat dilaksanakan antara lain dengan model pembelajaran "unggah-ungguh" di sekolah ${ }^{2}$. Tantangan globalisasi dan proses demokrasi yang semakin kuat dan beragam disatu pihak, dan dunia persekolahan sepertinya lebih mementingkan penguasaan dimensi pengetahuan dan mengabaikan pendidikan nilai/moral saat ini, merupakan alasan yang kuat bagi Indonesia untuk membangkitkan komitmen dan melakukan pendidikan karakter. Pendidikan karakter bangsa diharapkan mampu menjadi alternatif solusi berbagai persoalan tersebut. Kondisi dan situasi saat ini tampaknya menuntut pendidikan karakter yang perlu ditransformasikan sejak dini, yakni sejak pendidikan anak usia dini, pendidikan dasar, pendidikan menengah dan pendidikan tinggi secara holistik dan sinambung ${ }^{3}$.

Komitmen nasional tentang perlunya pendidikan karakter, secara imperatif tertuang dalam Undang-undang Nomor 20 Tahun 2003 tentang Sistem Pendidikan Nasional pasal 3. UU tersebut dinyatakan bahwa "Pendidikan nasional berfungsi mengembangkan kemampuan dan membentuk watak serta peradaban bangsa yang bermartabat dalam rangka mencerdaskan kehidupan bangsa, bertujuan untuk berkembangnya potensi peserta didik agar menjadi manusia yang beriman dan bertakwa kepada Tuhan Yang Maha Esa, berakhlak mulia, sehat, berilmu, cakap, kreatif, mandiri, dan menjadi warga negara yang demokratis serta bertanggung jawab." Jika dicermati sebagian besar potensi peserta didik yg ingin dikembangkan sangat terkait erat dengan karakter.

Pendidikan "unggah-ungguh" di sekolah merupakan pembelajaran tata krama yang biasa diterapkan dalam budaya jawa. Pendidikan "unggah-ungguh"menjunjung tinggi rasa sopan santun dalam kehidupan sehari-hari. "Unggah-ungguh" sebagai pedoman hidup yang memiliki pesan moral. Pendidikan unggah-ungguh memiliki dasar dalam memberikan pemahaman tentang pendidikan moral di sekolah, sehingga siswa memiliki landasan dalam bersikap dan bertingkah laku. Pendidikan unggah-ungguh mampu mengantarkan peserta didik

\footnotetext{
${ }^{2}$ Trihartini retnowati, makalah seminar nasional dalam Rangka Dies natalis ke 46 UNY. Selasa 16 Mei 2010

${ }^{3}$ Ibid
} 
menjadi manusia modern yang progresif, kritis,mandiri berbudi pekerti yang baik beraklhak mulia dan mampu mengusahakan perbaikan bagi diri serta masyarakatnya.

Pendidikan unggah-ungguh sebagai salah satu upaya mengembangkan kemampuan dan membentuk watak serta peradaban bangsa yang berakhlak mulia, sehat, berilmu, cakap, kreatif,mandiri, dan menjadi warga negara yang demokratis serta bertanggungjawab menjadi acuan pembelajaran di sekolah. Pendidikan unggah-ungguh penting dilaksanakan dalam proses belajar mengajar di sekolah, pendidikan "unggah-ungguh" memuat pembelajaran etika, estetika, susila, sopan santun dalam berpikir, bersikap dan bertingkah laku.

Pendidikan "unggah-ungguh" merupakan penerapan dari bagian rumpun pendidikan nilai. Dalam konteks kebangsaan, pendidikan nilai erat kaitannya dengan pembentukan dan pengembangan watak bangsa. Pendidikan nilai adalah suatu proses budaya yang selalu berusaha meningkatkan harkat dan martabat manusia, membantu manusia berkembang dalam dimensi intelektual, moral, spiritual, dan estetika yang memuat nilai-nilai ${ }^{4}$.

Kesadaran dan komitmen untuk memanfaatkan unggah-ungguh dalam program pendidikan di sekolah formal karena pendidikan "unggah-ungguh" memiliki karakteristik yang unik, bermakna, dan bermanfaat terhadap pertumbuhan dan perkembangan kepribadian peserta didik. Pertanyaan yang timbul adalah bagaimana membangun karakter peserta didik melalui pendidikan unggah-ungguh di sekolah? Kegiatan-kegiatan apa saja yang menunjang pendidikan unggah-ungguh dapat diselenggarakan di sekolah untuk mengembangkan karakter siswa?

\section{Pendidikan Karakter}

Pendidikan karakter merupakan investasi nilai kultural yang membangun watak, moralitas dan kepribadian masyarakat yang dilakukan dalam waktu panjang, kontinyu, intens, konstan dan konisten. Dengan demikian pendidikan karakter memberikan kepada siswa ilmu, pengetahuan, praktik-praktik budaya perilaku yang berorientasi pada nilai-nilai ideal kehidupan, baik yang bersumber dari budaya lokal (kearifan lokal) maupun budaya luar ${ }^{5}$.

Ditinjau secara akademik, pendidikan karakter dimaknai sebagai pendidikan nilai, pendidikan budi pekerti, pendidikan moral, pendidikan watak, yang tujuannya mengembangkan kemampuan peserta didik untuk memberikan keputusan baik-buruk, memelihara apa yang baik

\footnotetext{
4 Jazuli. (2008). Paradigma kontekstual pendidikan seni. Surabaya:Unesa University Press.

${ }^{5}$ Tranggono, Indra, Pendidikan Karakter. Kedaulatan Rakyat,26 April 2010
} 
itu, dan mewujudkan kebaikan dalam kehidupan sehari-hari dengan sepenuh hati. Lickona (1992) menyatakan bahwa muatan pendidikan karakter secara psikologis mencakup dimensi moral reasoning, moral feeling, dan moral behaviour ${ }^{6}$.

Pendidikan karakter dinilai berhasil apabila peserta didik menunjukkan kebiasaan berperilaku baik. Perilaku baik akan muncul dan berkembang pada diri peserta didik apabila memiliki sikap positif terhadap konsep karakter yang baik dan terbiasa melakukannya. Oleh karena itu, pendidikan karakter perlu dikemas dalam wadah yang komprehensif dan bermakna. Pendidikan karakter perlu diformulasikan dan dioperasionalkan melalui transformasi budaya dan kehidupan sekolah. Pendidikan karakter mempunyai misi yang sama dengan pendidikan akhlak atau pendidikan moral. Secara konseptual kata etika dan moral mempunyai makna yang serupa yaitu sama-sama membicarakan perbuatan dan perilaku manusia ditinjau dari sudut pandang nilai baik dan buruk. Namun penerapannya etika lebih pada tataran teoritis filosofis sebagai acuan untuk mengkaji sistem nilai, dan moral lebih pada tataran praktis sebagai tolok ukur untuk menilai perbuatan seseorang. Sedangkan karakter lebih menekankan pada aplikasi nilai-nilai positif dalam kehidupan sehari-hari dan tidak sekedar mengajarkan mana yang benar dan mana yang salah kepada anak, tetapi pendidikan karakter menanamkan kebiasan (habitution) tentang yang baik sehingga peserta didik paham, mampu merasakan, dan mau melakukan yang baik. Sejalan dengan hal tersebut di atas Doni berpendapat bahwa pendidikan karakter di sekolah mengacu pada proses penanaman nilai, berupa pemahaman-pemahaman, tata cara merawat dan menghidupi nilai-nilai itu, serta bagamana seorang siswa memiliki kesempatan untuk dapat melatihkan nilai-nilai tersebut secara nyata ${ }^{7}$. Ditinjau dari makna pendidikan karakter, Darmiyati (2009:10) berpendapat sesugguhnyalah pendidikan karakter mempunyai makna lebih tinggi dari pada pendidikan moral, karena bukan sekedar mengajarkan mana yang salah, lebih dari itu pendidikan karakter menanamkan kebiasaan (habituation) tentang hal yang baik sehingga peserta didik menjadi faham (domain kognitif) tentang mana yang baik dan salah, mampu merasakan ( domain afektif) nilai baik dan biasa melakukannya (domain perilaku). Dengan demikian pendidikan karakter harus ditanamkan melalui cara-cara yang rasional, logis,

\footnotetext{
${ }^{6}$ Lickona, T. (1992). Educating for character, how our schools can teach respect. Respect and Responsibility. New York: Bantam Books.

${ }^{7}$ Doni Koesoema, A. (2010). Pendidikan karakter. Jakarta: Grasindo.
} 
dan demokratis ${ }^{8}$. Dalam konteks kehidupan bermasyarakat, berbangsa, dan bernegara Indonesia, diyakini bahwa nilai dan karakter yang secara legal-formal dirumuskan sebagai fungsi dan tujuan pendidikan nasional, harus dimiliki peserta didik agar mampu menghadapi tantangan hidup pada saat ini dan di masa mendatang akan datang. Karena itu pengembangan nilai yang bermuara pada pembentukan karakter bangsa yang diperoleh melalui berbagai jalur, jenjang, dan jenis pendidikan, akan mendorong mereka menjadi anggota masyarakat, anak bangsa, dan warga negara yang memiliki kepribadian unggul seperti diharapkan dalam tujuan pendidikan nasional. Sampai saat ini, secara kurikuler telah dilakukan berbagai upaya untuk menjadikan pendidikan lebih mempunyai makna bagi individu yang tidak sekadar memberi pengetahuan pada tataran koginitif, tetapi juga menyentuh tataran afektif dan konatif melalui berbagai mata pelajaran.

Dalam Permendiknas N0.23/2006 tentang Standar kompetensi lulusan secara formal sudah digariskan untuk masing-masing jenis atau satuan pendidikan sejumlah rumusan Standar Kompetensi Lulusan (SKL). Jika dicermati secara mendalam, sesungguhnya hampir pada setiap rumusan SKL tersebut implisit atau eksplisit termuat substansi nilai/karakter.(BSNP, 2006). Berikut ini substansi nilai/karakter yang ada pada setiap SKL tersebut. antara lain: iman dan taqwa, jujur, disiplin, terbuka, nasionalistik, bernalar, kreatif, peduli, tanggung jawab, bersih, santun, gotong royong, gigih, bervisi, dan adil ${ }^{9}$. Pendidikan unggah ungguh sebagai pelaksanaan pendidikan nilai di sekolah diberikan karena keunikan, kebermaknaan dan kebermanfaatan terhadap kebutuhan perkembangan peserta didik, yang terletak pada pemberian pengalaman estetik dalam bentuk kegiatan berekspresi/berkreasi dan berapresiasi. melalui pendekatan : “ belajar unggah-ungguh", "belajar melalui unggah-ungguh", dan " belajar tentang unggahungguh.". Peran ini tidak dapat diberikan oleh mata pelajaran lain. Pengalaman estetik yang diberikan pada pembelajaran unggah-ungguh pada prinsipnya berfungsi melatih dan mengembangkan kepekaan rasa etika dan estetika. Dengan kepekaan rasa yang tinggi mental seseorang cenderung mudah diisi dengan nilai-nilai hidup dan kehidupan, seperti nilai religius, nilai moral, nilai budi pekerti dan nilai kehidupan lainnya. Pendidikan unggah-ungguh salah satu pelaksanaannya melalui pembelajaran unggah-ungguh di sekolah, aktivitas pembelajaran harus menampung kekhasan tersebut yang tertuang dalam pemberian pengalaman mengembangkan konsepsi, apresiasi, dan kreasi. Semua ini diperoleh melalui upaya eksplorasi elemen, prinsip,

\footnotetext{
${ }^{8}$ Darmiyati Zuchdi. (2009). Pendidikan karakter grand design dan nilai-nilai target. Yogyakarta: UNY Press.

${ }^{9}$ Trihartini retnowati, makalah seminar nasional dalam Rangka Dies natalis ke 46 UNY. Selasa 16 Mei 2010
} 
proses, dan berekspresi dalam konteks budaya masyarakat yang beragam. Pembelajaran "unggah-ungguh" di sekolah merupakan bagian dari pelaksanaan mata pelajaran seni budaya bertujuan agar peserta didik memiliki kemampuan sebagai berikut .

1. Memahami konsep dan pentingnya unggah-ungguh.

2. Menampilkan sikap apresiasi terhadap unggah-ungguh

3. Menampilkan kreativitas melalui pembelajaran unggah-ungguh

4. Meningkatkan peran serta pendidikan unggah-ungguh pada tingkat lokal, regional, maupun global.

5. Mengolah dan mengembangkan rasa humanistik ${ }^{10}$.

Pembelajaran unggah-ungguh merupakan pelaksanaan pendidikan seni budaya menurut PP 19 tahun 2005 diformulasikan dalam Kelompok Mata Pelajaran Estetika merupakan kolompok mata pelajaran yang tergolong unik karena melekatnya "pengalaman estetik" pada diri seseorang. Pengalaman estetik merupakan sesuatu yang esensial. Menurut Linderman (1977), pengalaman estetik mencakup pengalaman-pengalaman perseptual, kultural, dan artistik. Pengalaman perseptual dikembangkan melalui kegiatan kreatif, imajinatif, dan intelektual. Pengalaman kultural melalui kegiatan pemahaman terhadap hasil warisan budaya lama dan baru, sedangkan pengalaman artistik melalui kegiatan kreatif dan apresiatif ${ }^{11}$.

Dengan demikian pengalaman estetik memberi peluang untuk memahami dunia dari sudut pandangan yang berbeda dengan aspek pengetahuan. Cara memahami dunia yang ditawarkan oleh seni bersifat intuitif, tak terduga, dan kreatif, serta dikomunikasikan dalam bahasa warna, bunyi, gerak, atau isyarat yang simbolis. Kelompok Mata Pelajaran Estetika dilaksanakan pada semua jenjang pendidikan dari Sekolah Dasar sampai dengan Sekolah Menengah Atas atau yang sederajat dengan nama mata pelajaran Seni Budaya untuk SMP dan SMA atau sederajat, sedang pada tingkat SD nama mata pelajarannya Seni Budaya dan Ketrampilan. Sedangkan Standar Kompetensinya disebutkan dalam PP 19 tahun 2005 kelompok mata pelajaran Etika dan Estetika sebagai berikut: membentuk karakter peserta didik menjadi manusia yang memiliki rasa seni dan pemahaman budaya. Tujuan ini dicapai melalui muatan dan/atau kegiatan bahasa, seni dan budaya, keterampilan, dan muatan lokal yang relevan ${ }^{12}$.

\footnotetext{
${ }^{10}$ BSNP. (2006). Standar nasional pendidikan. Jakarta: BSNP

${ }^{11}$ Linderman, Earl. (1977). Art \& crafts for the classroom.USA:Macmillan Publishing Company.

12 Ibid
} 
Dengan demikian cakupan kelompok mata pelajaran Estetika dimaksudkan untuk meningkatkan sensitivitas, kemampuan mengapresiasi dan kemampuan mengekspresikan keindahan dan harmoni. Kemampuan tersebut mencakup apresiasi dan ekspresi, baik dalam kehidupan individual sehingga mampu menikmati dan mensyukuri hidup maupun dalam kehidupan kemasyarakatan sehingga menciptakan kebersamaan yang harmonis.

Pendidikan unggah-ungguh di sekolah termasuk pada mata pelajaran Seni Budaya. Seperti diketahui unggah-ungguh adalah warisan budaya Indonesia khususnya budaya jawa yang adiluhung sehingga perlu dilestarikan keberadaanya di sepanjang zaman. Proses aplikasi pendidikan karakter dengan menerapkan unggah-ungguh dalam proses belajar mengajar akan menjadi kebiasaan bagi siswa, guru dan civitas di sekolah, sehingga terbentuk pribadi lingkungan peserta didik yang progresif dan berbudi pekrti luhur. Dengan demikian adanya pembelajaran unggah-ungguh di sekolah merupakan sarana pengembangan karakter siswa.

\section{Pendidikan Unggah-ungguh}

\section{Pengertian Unggah-ungguh}

Adisumarto (dalam Suharti, 2001: 69) menyatakan bahwa "unggah-ungguh bahasa Jawa adalah adat sopan santun, etika, tatasusila, dan tata krama dalam berbahasa Jawa." Berdasarkan pengertian tersebut nampak bahwa unggah-ungguh bahasa dalam bahasa Jawa atau sering disebut tingkat tutur atau undha usuk basa tidak hanya terbatas pada tingkat kesopanan bertutur (bahasa Jawa ragam krama dan ngoko) saja, namun di dalamnya juga terdapat konsep sopan santun bertingkah laku atau bersikap ${ }^{13}$.

Di dalam pendidikan unggah-ungguh, sarana pendidikan sopan santun anak dapat dikembangkan. Hal tersebut sejalan dengan pendapat Sabdawara (2001) bahwa bahasa Jawa dapat digunakan sebagai wahana pembentukan budi pekerti dan sopan santun karena kaya dan lengkap dengan perbendaharaan kata sebagai bahasa yang meliputi: fungsi, aturan atau norma kebahasaan, variasi atau tingkatan bahasa, etika dan nilai-nilai budaya yang tinggi dengan segala peran fungsinya. Adapun fungsi bahasa Jawa menurut Sabdawara (2001: 127-128) antara lain sebagai berikut:

\footnotetext{
${ }^{13}$ Adisumarto (dalam Suharti, 2001: 69)
} 
a. Bahasa Jawa adalah bahasa budaya di samping berfungsi komunikatif juga berperan sebagai sarana perwujudan sikap budaya yang sarat dengan nilai-nilai luhur,

b. Sopan santun berbahasa Jawa berarti mengetahui akan batas-batas sopan santun, mengetahui cara menggunakan adat yang baik dan mempunyai rasa tanggung jawab untuk perbaikan hidup bersama.

c. Agar mencapai kesopanan yang dapat menjadi hiasan diri pribadi seseorang, maka syarat yang harus dipenuhi adalah sebagai berikut:

1) Pandai menenggangkan perasaan orang lain di dalam pergaulan,

2) Pandai menghormati kawan maupun lawan,

3) Pandai menjaga tutur kata, tidak kasar, dan tidak menyakiti hati orang lain ${ }^{14}$.

Berdasarkan pendapat tersebut di atas, maka sangatlah tepat bahwa sejak usia dini, anak-anak diperkenalkan dan diajarkan tentang unggah-ungguh bahasa Jawa karena sebagai landasan perkembangan perilaku pada periode selanjutnya. Orang tua dan pendidik hendaknya tidak bosan dan lelah untuk selalu memberikan nasihat, teladan, ruang pilihan, kesempatan untuk mengambil keputusan, keleluasaan bagi anak-anak untuk meneladan, mengikuti dan menilai baik dan buruk, benar salah suatu sikap, perilaku atau perbuatan.

\section{Pengertian Pendidikan Unggah-ungguh}

Pendidikan unggah-ungguh merupakan pengetahuan tentang etika, estetika dan tata krama, tata susila, perilaku baik dalam pergaulan, pekerjaan dan dalam kehidupan sehari-hari. Tujuan utama pendidikan unggah-ungguh adalah menanamkan nilai moral kepada siswa, bertingkah laku sopan,santun dan mandiri ${ }^{15}$. Carter V.Good (1977) menyatakan bahwa "pendidikan adalah proses perkembangan kecakapan seseorang dalam bentuk sikap dan prilaku

yang berlaku dalam masyarakatnya. Proses sosial dimana seseorang dipengaruhi oleh suatu lingkungan yang terpimpin (khususnya di sekolah) sehingga ia dapat mencapai kecakapan sosial dan mengembangkan kepribadianya ${ }^{16}$

Ki Hajar Dewantara mengartikan “ pendidikan sebagai daya upaya untuk memajukan budi pekerti, pikiran serta jasmani anak agar dapat memajukan kesempurnaan hidup yaitu hidup

\footnotetext{
${ }^{14}$ Sabdawara (2001: 127-128)

${ }^{15}$ Yana MH,2010, Falsafah dan Pandangan Hidup Orang jawa, Yogyakarta, Absolut

${ }^{16}$ Ibid
} 
dan menghidupkan anak yang selaras dengan alam dan masyarakatnya."17 Unggah-ungguh merupakan istilah dalam budaya jawa, dilihat dari sudut bahasa, unggah-ungguh merupakan kata-kata atau ungkapan khusus dalam bahasa jawa yang amencerminkan sikap budaya atau tata krama orang Jawa, terutama dalam berinteraksi dengan orang lain, misalnya ungkapan yang biasa digunakan dalam masyarakat jawa. Contoh : nuwun sewu (permisi), nderek langkung (perkenankan lewat sini), adalah ungkapan dalam bahasa Jawa yang memiliki makna.

Unggah-ungguh sebagai cerminan masyarakat Jawa menampilkan suatu profil bahasa yang sangat menarik. Dalam hal ini bahasa bukanlah sekedar wahana komunikasi yang efisien dan kepraktisannya dapat menjadi dasar yang paling utama, melainkan bahasa sekaligus menjadi manifestasi status sosial para pembicara dan pendengarnya. Dengan demikian bahasa Jawa bukan sekedar alat komunikasi melainkan sekaligus merupakan alat penunjuk stratifikasi sosial yang harus dipatuhi oleh para warganya ${ }^{18}$.

Sebagai sebuah tata krama, unggah-ungguh juga mencakup semua tindak-tanduk manusia yang terekopresikan dapala bentuk sikap dan tingkah laku. Artinya, tata krama merupakan sifat lahiriah yabng keluar dari diri seseorang. Tata krama atau sopan santun juga berhubungan erat denganh seluruh kehidupan masyarakat, derajat,pangkat, selera, bakat dan pandangan hidup. Menurut tempat atau wilayahnya, tata krama diklasifikasi menjadi 3 (tiga) yaitu : (1) tata krama di rumah; (2) tata krama di sekolah dan (3) tata krama di masyarakat. Dari ketiga lingkungan tersebut anak didik akan mendapatkan pembelajaran tentang nilai-nilai tata krama, budi pekerti luhur, nilai-nilai agama termasuk akhlaq. Salah satu contoh penerapan pembelajaran ungguh-ungguh dalam kehidupan sehari-hari adalah dengan menghormat kepada orang tua atau orang yang lebih tua, dengan perilaku sedikit membungkuk jika berjalan didepan orang tua dan dengan sopan sambil mengucap "nuwun sewu" (permisi), nderek langkung (perkenankan lewat sini). Selain berperilaku halus dan sopan juga berbahasa yang baik untuk menghormati sesama, apakah itu bahasa halus (kromo) atau ngoko (bahasa biasa). Bahasa jawa yang bertingkat bukanlah hal yang rumit, karena unggah-ungguh basa (penggunaan bahasa menurut tingkatnya) adalah sopan santun untuk menghormati orang lain berdasarkan lawan bicara.

\footnotetext{
${ }^{17}$ Blogspot.com,2007

${ }^{18}$ Poedjosoedarmo,1979
} 
Mendasarkan uraian diatas dapat didefinisikan bahwa pendidikan unggah-ungguh, yaitu usaha sadar seorang melalui proses pengembangan diri dalam berpikir, bersikap dan perilaku tata krama sehingga terbentuk pola pikir, sikap dan prilaku yang berakhlaq mulia, bertingkah laku yang sopan, santun dan mandiri.

\section{Tujuan Pendidikan Unggah-ungguh}

Tujuan penerapan pendidikan unggah-ungguh melalui pembelajaran unggah-ungguh, yaitu :

a. Siswa memiliki pengetahuan, pemahaman dan melestarikan unggah-ungguh di sekolah. Sebagai contoh : menerapkan ungkapan-ungkapan dalam bahasa Jawa jika berhadapan dengan orang yang lebih tua. Misalkan : nyuwun sewu, nderek langkung, matur nuwun dan lain sebagainya.

b. Siswa memiliki pengetahuan dan pemahaman tentang unggah-ungguh sehingga melalui pendidikan unggah-ungguh dapat menunjang pembinaan moral, misalnya: menggunakan bahasa yang lebih halus jika berbicara dengan orang tua, dengan tujuan menghormati yang lebih tua.

c. Siswa memperoleh bekal tentang tata krama untuk melaksanakan tugas-tugas hidupnya secara selaras, serasi, seimbang ( lahir, batin, material, spiritual dan individual sosial).

d. Membiasakan peserta didik untuk bersikap dan bertingkah laku yang sesuai dengan tuntutan agama dan budaya bangsa dalam menghadapi masalah hidup sekarang atau di masa yang akan datang.

e. Mengarahkan dan merangsang siswa untuk menggunakan akan pikirannya atau rasio untuk dapat membedakan tindakan atau perbuatan baik dan buruk dalam kehidupan.

f. Siswa memiliki landasan berpikir, bersikap, dan berperilaku di lingkungan keluarga, sekolah dan masyarakat ${ }^{19}$.

Dengan rumusan tujuan dari penerapan pendidikan nilai melalui pembelajaran unggahungguh, diharapkan dapat memperoleh gambaran fungsi pendidikan nilai/unggah-ungguh sebagai perwujudan pendidikan moral sehingga mampu meningkatkan kedisiplinan siswa dalam bertata krama, memiliki landasan dalam berpikir, bersikap dan berperilaku di lingkungan keluarga, sekolah dan masyarakat, serta mampu berinteraksi dengan harmonis, menghargai orang

\footnotetext{
${ }^{19}$ Soenarjati Moehadjir,2005, dalam Hand out Pendidikan moral FKIP UCY,2005
} 
lain dan mengembangkan perbuatan-perbuatan yang luhur yang mencerminkan sikap serta suasana kekeluargaan dan kegotongroyongan.

\section{Fungsi Pendidikan Unggah-ungguh.}

Fungsi pendidikan unggah-ungguh adalah sebagai berikut :

a. Merupakan alat pembelajaran sekaligus dapat memberikan pengetahuan pada anak tentang makna dan implementasi dari sikap sopan santun. Beberapa fungsi pentingnya pendidikan unggah-ungguh antara lain:

1) Pembentukan kepribadian

2) Pendidikan unggah-ungguh membantu mengajarkan keseimbangan serta kesesuaian antara kesantunan batin dan kesantunan perilaku.

3) Suatu kesepatan sosial, diwujudkan ke dalam sejumlah sarana berkenaan dengan berbagai arena kehidupan manusia.

4) Sebuah proses penyesuaian di antara unsur-unsur yang saling berbeda dalam kehidupan masyarakat yang memiliki keserasian.

5) Memberikan kontribusi berupa pengetahuan dalam memahami, mengolah dan mengaplikasikan sikap kesopanan dalam kehidupan bermasyarakat, sebagai bentuk tata cara bersikap dalam budaya jawa yang sarat akan aturan ${ }^{20}$

b. Meningkatkan keimanan dan ketaqwaan kepada Tuhan Yang Maha Esa yang telah ditanamkan dalam lingkungan keluarga, lingkungan masyarakat maupun sekolah.

1) Memperbaiki kesalahan-kesalahan dalam bersikap dan bertingkah laku dalam kehidupan sehari-hari, termasuk perbaikan tindakan-tindakan negatif, dengan tujuan perbaikan kearah yang lebih baik

2) Menjaga dan menerapkan kebudayaan nasional dengan mewujudkannya dalam tata krama di lingkungan sekolah, sehingga dapat memilih kebudayaan asing yang tidak sesuai dengan jati diri bangsa Indonesia.

Dari beberapa fungsi tersebut diatas, maka alasan yang melandasi penerapan unggah - ungguh di sekolah antara lain :

a. Sekolah merupakan tempat pendidikan formal yang dipandang sebagai faktor yang mmpercepat proses pemahaman unggah-ungguh, sehingga anak mendapatkan asupan

\footnotetext{
${ }^{20}$ Yana MH,2010, Falsafah dan Pandangan Hidup Orang jawa, Yogyakarta, Absolut
} 
norma-norma dengan menggunakan strategi dan metode efektif untuk pembelajaran dan pendidikan.

b. Pendidikan moral sangat essensial untuk mengembangkan sumber daya manusia (SDM) yang berkualitas dan membangun masyarakat yang bermoral ${ }^{21}$.

c. Dibutuhkan sosok guru berkepribadian yang baik, serta menjunjung tinggi kebuyaan nasional dalam bersikap dan bertingkah laku di sekolah.

Hilangnya sikap sopan santun sbagian siswa merupakan salah satu dari sekian penyebab kurang terbentuknya karakter. Tidak terpeliharanya sikap sopan dan santun ini dapat berdampak negatif terhadap budaya bangsa Indonesia yang dikenal sebvagai bangsa yang menjunjung tinggi nilai-nilai moral dan kehidupan yang beradab. Sebagian anak remaja mulai berani kepada orang tua, berani kepada gurunya, bila diberi nasehat berani membantah bahkan mungkin menentang pada orang yang menasehati. Sikap seperti ini banyak kita temui pada pelajar. Kondisi ini menunjukkan bahwa sekolah baru menghasilkan siswa yang memiliki intelektual tinggi, namun tidak memiliki karakter yang ditunjukkan oleh kurangnya akhlaq mulia yang dimilikinya. Pembinaan sikap sopan santun, sosial dan tata krama melalui proses pembudayaan unggahungguh di sekolah diharapkan dapat tercapai tujuan pendidikan nasional.

Dalam UU No. 20 Tentang Pendidikan Nasional tahun 2003 dinyatakan bahwa : Pendidikan nasional berfungsi mengembangkan kemampuan dan membentuk watak serta peradaban bangsa yang bermartabat dalam rangka mencerdaskan kehidupan bangsa, bertujuan untuk berkembangnya potensi peserta didik agar menjadi manusia yang beriman dan bertakwa kepada Tuhan Yang Maha Esa, berakhlaq mulia, sehat, berilmu, cakap, kreatif, mandiri, dan menjadi warga negara yang demokrasi serta bertanggungjawab ${ }^{22}$.

\section{Membangun Karakter Siswa Melalui Pendidikan Unggah-ungguh di Sekolah Metode Penerapan Pendidikan Unggah-ungguh}

Penerapan pendidikan unggah-ungguh di sekolah haruslah menggunakan metode atau model pembelajaran unggah-ungguh yang tepat. Dengan model pembelajaran unggah-ungguh

\footnotetext{
${ }^{21}$ Lickona, T. (1992). Educating for character, how our schools can teach respect. Respect and Responsibility. New York: Bantam Books.

${ }^{22}$ UU No.20 Tentang Pendidikan Nasional tahun 2003
} 
yang tepat para siswa diharapkan akan dapat mengerti, memahami, mensikapi, menghayati dan melaksanakan pendidikan unggah-ungguh dengan baik.

Mengacu pada model Pembelajaran Emile Durkheim (1990). Pembelajaran unggahungguh dapat dilakukan melalui ${ }^{23}$ :

\section{Metode Pembiasaan}

Metode pembiasaan terutama dipergunakan untuk membangun kedisiplinan, terdapat 2 (dua) unsur dalam pengembangan disiplin, yaitu keinginan tidak berlebihan dan penguasaan diri. Disiplin merupakan cara untuk merangsang kemauan anak dalam proses pembelajaran. Anak harus dilatih menaati kaidah paraturan, sehingga dapat merasakan adanya sesuatu yang patut dihormati yaitu otoritas perilaku yang ditanamkan pada anak. Dengan begitu anak memiliki rasa tanggungjawab atas segala tindakan yang akan dilakukan, serta berusaha menghindari perbuatan atau tindakan yang menyimpang. Disini anak dapat membedakan mana yang boleh dilakukan dan mana yang harus dihindari.

\section{Metode Hukuman}

Hukuman diperlukan untuk mentaati kaidah peraturan dan penyampaian kepada anak, sehingga mereka mematuhi peraturan tersebut. Oleh sebab itu, hukuman yang diberikan harus sesuai dengan pelanggaran yang dilakukan, tidak boleh terlalu berat dan harus bijaksana, sehingga anak tidak merasa dipermainkan. Hukuman tidak dapat selalu digunakan sebab dapat menimbulkan dampak psikologis dan jasmani anak menjadi terganggu jika frekuensi penerapan hukuman sering dan memaksa.

\section{Penumbuhan Solidaritas Pada Anak}

Lingkungan sekolah terdiri dari siswa yang melakukan aktifitas bersama, guru dan berbagai komponen penunjang pendidikan. Sekolah dapat dijadikan sarana yang tepat untuk melatih siswa dalam kebiasaan hidup berkelompok, dan sosial, menumbuhkan kesadaran akan adanya kebutuhan yang harus dipenuhi bersama, terikat dan kolektif. Dalam proses pembelajaran kadang sering dilakukan metode pemberian tugas kelompok untuk melatih anak bermusyawarah dan menghargai pendapat orang lain.

\footnotetext{
${ }^{23}$ Emile Durkaheim, 1990:72
} 


\section{Metode Keteladanan.}

Guru merupakan panutan dalam segala hal, termasuk pembinaan akhlaq. Keteladanan merupakan strategi dan metode efektif untuk pembelajaran dan pendidikan, sebab keteladanan yabng ditunjukkan oleh seorang guru merupakan faktor penting yang berpengaruh terhadap berhasil tidaknya penanaman nilai moral ${ }^{24}$.

Dalam konteks penerapan model pembelajaran unggah-ungguh metode pembiasaan dan keteladanan tepat untuk dipergunakan. Agar supaya penerapan pembelajaran unggah-ungguh dapat berjalan dengan baik dan terpadu, pembudayaan sopan santun di sekolah melalui peran guru dalam mendidik muridnya. Dalam hubungan ini, guru dapat melakukan hal-hal sebagai berikut :

a. Memberikan contoh-contoh penerapan perilaku sopan santun di depan anak. Contoh keteladanan merupakan alat pendidikan yang sekaligus dapat memberikan pengetahuan pada anak tentang makna dan implementasi dari sikap sopan santun itu sendiri ${ }^{25}$.

b. Menanamkan sikap sopan santun melalui pembiasaan. Siswa dibiasakan bersikap sopan santun dalam kehidupan sehari-hari di sekolah, dengan cara mengucap salam, aturan bersalaman dan beberapa kegiatan yang menumbuhkan sikap tata krama.

c. Guru dapat membantu pembiasaan sopan santun melalui kegiatan proses belajar mengajar.

Penerapan model pembelajaran unggah-ungguh yang tepat akan dapat mewujudkan keberhasilan pendidikan moral, terutama terlaksananya proses pembudayaan sikap sopan santun, tata krama di sekolah, dan tentunya akan berdampak pula pada keluarga dan masyarakat.

Pengembangan karakter melalui pendidikan unggah-ungguh di sekolah, secara prinsip dapat dilaksanakan terintegrasi dengan mata pelajaran Seni Budaya dengan memasukan pengembangan karakter pada pokok bahasan yang akan diajarkan dalam silabus dan RPP. Oleh karena itu guru dan sekolah perlu mengintegrasikan nilai-nilai yang dikembangkan dalam pendidikan budaya dan karakter bangsa ke dalam Kurikulum Tingkat Satuan Pendidikan (KTSP, silabus dan RPP) yang sudah ada. Prinsip pembelajaran yang digunakan dalam pembelajaran unggah-ungguh merupakan pengembangan pendidikan budaya dan karakter bangsa adalah mengusahakan agar siswa mengenal dan menerima nilai-nilai budaya dan karakter bangsa sebagai milik mereka dan bertanggung jawab atas keputusan yang diambilnya melalui tahapan

\footnotetext{
24 www.wordperss.com:1999

25 Dyah Kusuma, dalam http//indteacher.wordperss.com;2009.
} 
mengenal pilihan, menilai pilihan, menentukan pendirian, dan selanjutnya menjadikan suatu nilai sesuai dengan keyakinan diri.

Dengan prinsip ini siswa belajar melalui proses berpikir, bersikap, dan berbuat. Ketiga proses ini dimaksudkan untuk mengembangkan kemampuan siswa dalam melakukan kegiatan sosial dan mendorong siswa untuk melihat diri sendiri sebagai makhluk sosial. Substansi nilai/karakter yang ada pada setiap SKL antara lain seperti yang disebutkan di atas yaitu: iman dan taqwa, jujur, disiplin, terbuka, nasionalistik, bernalar, kreatif, peduli, tanggung jawab, bersih, santun, gotong royong, gigih, bervisi, dan adil. Pelaksanaannya pada pembelajaran unggah-ungguh di integrasikan dalam pemberian pengalaman etika dan estetik dalam bentuk kegiatan pembiasaan dan keteladanan dalam berapresiasi, berekspresi dan berkreasi. Dengan demikian membangun karakter siswa melalui pembelajaran unggah-ungguh dapat dilaksanakan melalui proses pembelajaran, yaitu peserta didik belajar aktif dan berpusat pada anak. Dapat pula dilakukan melalui berbagai kegiatan di sekolah. Kegiatan tersebut direncanakan sejak awal tahun pelajaran, dan dimasukkan ke Kalender Akademik. Contoh kegiatan yang dapat dimasukkan ke dalam program sekolah antara lain: lomba berinteraksi, seni tradisional ( misal : ketoprak, wayang orang, drama dsb).

Pengembangan proses pendidikan unggah-ungguh dalam hal ini mata pelajaran Seni budaya dalam rangka membangun karakter siswa dapat melalui kegiatan di kelas dengan dirancang terlebih dahulu. Kegiatan pembelajarannya tentunya meliputi ranah kognitif, afektif, dan psikomotor seperti pelajaran yang lain. Kemudian diintegrasikan dengan nilai karakter yang akan dikembangkan. Pendidikan unggah-ungguh yaitu pemberian pengalaman etika dan estetik dalam bentuk kegiatan berekspresi/berkreasi dan berapresiasi serta pembiasaan dalam tata krama kehidupan sehari-hari. Integrasi yang bisa dikembangkan misal: dalam hal apresiasi, dengan belajar sopan santun dan tata krama, teori sopan santun dan tata krama, sejarah kebudayaan, dan lain-lain. Pengembangan nilai-nilai yang dapat dikembangkan antara lain: Iman dan Taqwa dengan mengagumi kebesaran sang Pencipta yang sangat indah segala ciptaannya, semangat kebangsaan, cinta tanah air, penghargaan terhadap hasil budaya nasional, dan sebagainya. Sedangkan pada kegiatan ekspresi/kreasi dapat dikembangkan nilai-nilai antara lain: jujur, mandiri, kreatif dan bertanggung jawab serta dapat menghargai sesama. Pengintegrasian nilai-nilai dan karakter pada pendidikan unggah-ungguh dapat pula dilakukan 
dengan mencantumkan dalam silabus mata pelajaran Seni Budaya. Cara yang bisa dilakukan adalah sebagai berikut:

1. Menentukan kandungan nilai-nilai karakter dengan mengkaji lebih dahulu Standar Kompetensi dan Kompetensi Dasar mata pelajaran Seni Budaya.

2. Mencamtumkan kandungan nilai-nilai karakter yang akan dikembangkan dengan melihat keterkaitan SK/KD dengan indikator pada kolom terakhir pada silabus.

3. Mencantumkan nilai-nilai karakter yang sudah tercantum dalam silabus ke RPP.

\section{Kesimpulan dan Saran}

\section{Kesimpulan}

Berbagai tindak kejahatan dan tindakan tidak bermoral terutama dilakukan oleh anak dan remaja yang marak terjadi di negara kita ini, mengindikasikan perlunya pendidikan karakter untuk membentuk generasi yang berkualitas. Sampai saat ini, secara kurikuler telah dilakukan berbagai upaya untuk menjadikan pendidikan lebih mempunyai makna bagi individu yang tidak sekadar memberi pengetahuan pada tataran kognitif, tetapi juga menyentuh tataran afektif dan konatif melalui pendidikan unggah ungguh. Melalui pendidikan unggah-ungguh secara praktis dan sesuai dengan kehidupan sehari-hari, dapat membiasakan anak didik untuk berperilaku sopan. Selain itu juga dapat dijadikan acuan anak didik ketika berperilaku dengan penuh kesantuan dalam interaksi dengan lingkungan sosial di sekitarnya. Pembelajaran unggah-ungguh di sekolah mempunyai peran dalam menanamkan dan menumbuhkan nilai-nilai sopan santun bagi anak didik dan dapat membangun karakter bangsa, dikembangkan karakter anak didik menjadi insan yang berkualitas.

Pendidikan unggah-ungguh merupakan pelaksanaan pendidikan seni budaya di sekolah diberikan karena keunikan, kebermaknaan dan kebermanfaatan terhadap kebutuhan perkembangan peserta didik, yang terletak pada pemberian pengalaman etika dan estetik dalam bentuk kegiatan berekspresi/berkreasi dan berapresiasi serta keteladanan dan pembiasaan dalam kehidupan sehari-hari. Pengalaman etika dan estetik yang diberikan melalui pembelajaran unggah-ungguh pada prinsipnya berfungsi melatih dan mengembangkan kepekaan rasa . Dengan kepekaan rasa yang tinggi mental seseorang cenderung mudah diisi dengan nilai-nilai hidup dan kehidupan, seperti nilai religius, nilai moral, nilai budi pekerti ( melatih disiplin, teliti, sabar, 
bersih, menghargai sesama dll). Pelaksanaannya melalui proses pembelajaran yaitu peserta didik belajar aktif dan berpusat pada anak, dilakukan melalui berbagai kegiatan berkaitan dengan pembelajaran unggah-ungguh yang direncanakan sejak awal sekolah dan dimasukan ke Kalender Akademik. Sedangkan pengembangan karakter yang terintegrasi dengan pembelajaran unggah-ungguh dilakukan dengan memasukan pengembangan karakter pada setiap pokok bahasan yang akan diajarkan dalam silabus dan RPP.

\section{Saran}

Sebagai saaran dari tulisan ini adalah sebagai berikut:

a. Dinas Pendidikan hendaknya mengadakan kajian dan sosialisasi tentang metode pembelajaran unggah-ungguh bagi guru-guru pengampu mata pelajaran seni rupa budaya yang dikaitkan dengan pendidikan karakter

b. Kepala sekolah hendaknya mendorong dan memfasilitasi guru pengampu mata pelajaran seni budaya untuk menerapkan pendidikan karakter melalui pembelajaran unggah-ungguh yang di laksanakan di sekolah.

\section{Daftar Pustaka}

Adisumarto (dalam Suharti, 2001: 69)

BSNP. (2006). Standar nasional pendidikan. Jakarta: BSNP

BSNP. (2006). Standar kompetensi lulusan.. Jakarta: BSNP.

Blogspot.com,2007

Carter V.Good (1977)

Darmiyati Zuchdi. (2009). Pendidikan karakter grand design dan nilai-nilai target. Yogyakarta: UNY Press.

Depdiknas. 2001. Pedoman Umum Pendidikan Budi Pekerti Pada Jenjang Pendidikan Dasar dan Menengah I. Jakarta: Ditjen Dikdasmen Depdiknas.

Doni Koesoema, A. (2010). Pendidikan karakter. Jakarta: Grasindo.

Emile Durkaheim, 1990:72

Jazuli. (2008). Paradigma kontekstual pendidikan seni. Surabaya:Unesa University Press. 
Lickona, T. (1992). Educating for character, how our schools can teach respect. Respect and Responsibility. New York: Bantam Books.

Linderman, Earl. (1977). Art \& crafts for the classroom.USA:Macmillan Publishing Company.

Poedjosoedarmo,1979

Sabdawara. 2001. Pengajaran Bahasa Jawa Sebagai Wahana Pembentukan Budi Pekerti Luhur. Makalah Konggres. Yogyakarta: Konggres Bahasa Jawa III.

Suharti.,2001,Pembiasaan Berbahasa Jawa Krama dalam Keluarga Sebagai Sarana Pendidikan Sopan Santun. Makalah Konggres. Yogyakarta: Konggres Bahasa Jawa III.

Soenarjati Moehadjir, Hand Out Pendidikan Moral FKIP Universitas Cokroaminoto Yogyakarta, 2005

Tatam S Mamat,2006, Masyarakat Jawa, Yogyakarta: Galang Perss.

Tim Pendidikan Karakter, (2010). Grand design pendidikan karakter. Jakarta: Kementrian Pendidikan Nasional

Tranggono, Indra.(26 April 2010), Pendidikan Karakter. Kedaulatan Rakyat, Hal 27.

Trihartini Retnowati, makalah seminar nasional dalam Rangka Dies natalis ke 46 UNY. Selasa 16 Mei 2010

UU No.20 Tentang Pendidikan Nasional tahun 2003

www.wordperss.com:1999

Yana MH,2010, Falsafah dan Pandangan Hidup Orang jawa, Yogyakarta, Absolut 